\title{
Timor-Leste: Multilingual Education for All?
}

\author{
Kerry Taylor-Leech \\ Griffith Institute for Educational Research, Griffith University, Queensland, Australia
}

\begin{abstract}
This article presents a review of medium-of-instruction policy in Timor-Leste after ten years of independence. The review is set against the provisions for language in the country's National Constitution and the human development discourses of the Education for All (EFA) and Millennium Development Goals (MDGs). It is informed by a range of literature dealing with language policy and the medium of instruction in linguistically diverse and developing contexts. The article provides an overview of the language situation and the development challenges facing education planners, followed by a critical examination of medium-of-instruction policy over the period 2000-2012. This critique is followed by an explanatory discussion of the mother tongue-based multilingual education (MTB-MLE) policy for Timor-Leste and a consideration of some concerns about MTB-MLE. The article closes with an assessment of the potential of this policy to promote linguistic diversity in Timor-Leste and help deliver on the EFA and MDGs for 2015.
\end{abstract}

Keywords: Timor-Leste; Education for All; Millennium Development Goals; language in education; medium-of-instruction policy; linguistic diversity; mother tongue-based multilingual education.

\section{Introduction}

Two global initiatives underpin development discourses in the twenty-first century: The Education for All (EFA) initiative aims to bring the benefits of education to every citizen in every society (UNESCO, Education) while the Millennium Development Goals (MDGs) set eight common human development targets: Gender equality, alleviation of poverty and hunger, universal primary 
education, reduced child mortality and maternal health, control of disease, sustainability of the environment and global partnerships for development ("The Millennium Development Goals"). Timor-Leste is among the countries that have pledged their commitment to achieving EFA and the MDGs by 2015.

The achievement of EFA is the key to attaining both sets of goals because, as Trudell points out, their achievement depends on effective communication in order to enable the spread of information and enhance community understanding (338). For example, the link between literacy and improved maternal and child health is now well established. The literate ability to access information can play a role in combating preventable disease, improving public health, lifting people out of poverty, promoting gender equality, and encouraging environmentally responsible practices. From this perspective, the achievement of universal primary education in young, post-colonial nations like Timor-Leste is perhaps the most important human development goal. When perceived in this way, the global EFA and MDGs become concerns of a more localised, "glocal" nature (Trudell 338), particularly in diverse and developing contexts.

In this article I offer an analysis of education language planning in Timor-Leste from this "glocal" perspective. I suggest that the greatest chance of achieving universal access to education lies in the pursuit of multilingualism for all. The first part of the article sets the scene with a brief overview of the current challenges to achieving EFA in Timor-Leste. It goes on to review the language situation and the educational policy context, identifying some legislative and policy initiatives that have bearing on the use of languages in education. The article then focuses on the mother tongue-based multilingual education (MTB-MLE) policy for Timor-Leste and assesses its potential to assist in achieving multilingual education for all.

\section{Language and development}

Between 2001 and 2007, despite a worrying increase in consumption poverty in Timor-Leste, there were signs of improvement in its education indicators. According to UNDP estimates, the population aged 6 years and above who had no formal schooling fell from 45 to $40 \%$ while adult literacy rose from 38 to $51 \%$; primary school completions increased from 31 to $43 \%$ and secondary 
school completions from 12 to 15\% ("The Millennium Development Goals"). These improved indicators are encouraging but Timor-Leste still faces great challenges to the achievement of EFA. At present, only $11 \%$ of children attend pre-school (TLSDP 16) and, according to the 2010 Census, net primary school enrolment stands at only $70.8 \% .{ }^{1}$ Although the $79.1 \%$ of East Timorese aged between 15 and 24 who can read or write in any of the languages recognised in the Constitution is an improvement on previous years, the fact that so many young people remain illiterate does not bode well for their employment prospects and their ability to build secure economic futures or become active, well informed, citizens.

Three of the greatest challenges to EFA are low enrolment, grade repetition and high dropout rates, particularly in the later primary grades. At least $70 \%$ of students do not reach Grade 6, let alone complete primary education (MOE, Education 23). Most dropouts occur before Grade 2, with Grade 9 enrolments standing at less than a quarter of those in Grade 1. High rates of grade repetition result in overcrowding and overage children in early grades. Dropout and repetition increase the costs, reduce the consistency and compromise the effectiveness of children's education. Low student retention can be attributed to a complex range of causes (Hunt 7-43) including long distances between home and school, parental concerns about safety, especially for girls, inadequate water and lack of hygienic facilities in schools, financial barriers and low levels of parental education, and understanding (Sabates et al. 12-13). However, it is now widely recognised that the use of a second or foreign language for instruction plays a major role in educational underachievement, poor literacy development and early dropout. ${ }^{2}$ Language problems affect an estimated 221 million children worldwide who are speakers of local languages not used for teaching (Pinnock et al. 6). These effects have been shown to be most severe for rural children in poor areas of developing countries (Smits et al. 18). Numerous studies show that school attendance and retention figures improve and academic performance is enhanced when first languages are used as languages of instruction. ${ }^{3}$ 


\section{Linguistic diversity in Timor-Leste}

Multilingualism is a daily fact of life in this ethnolinguistically diverse society. Some 30 language varieties are used in East Timorese homes; indeed, many families and communities use more than one. Estimates of their number differ according to ways of classifying languages and dialects (Bowden and Hajek 265) and how their speakers perceive them. Ethnologue lists 19 languages (Lewis), while Hull identifies 16 languages with dialectal variations (4). The 2004 Population Census listed 32 indigenous language varieties mentioned by respondents (National Bureau of Statistics 80 ). ${ }^{4}$ Tetum-Praça, an urban variety of Tetum that functions as a lingua franca across most (but not all) districts, is spoken as a first language in Dili and as a second language throughout much of the rest of the country. Several other varieties of Tetum are also used as first languages in rural and remote districts. In addition, Timor-Leste's experience of subjugation by two successive colonial powers and a period under transitional administration by the United Nations (UN) has left three dominant foreign languages, Portuguese, Indonesian and English, competing for status. The 2002 Constitution opted for plurilingualism, conferring co-official status on Portuguese and Tetum, also adopting Indonesian and English as working languages to be used in the civil service alongside the co-official languages. Tetum and the indigenous vernaculars were accorded the status of national languages, to be protected and valued by the State. This multilingual language situation has generated much debate over the use of languages for instructional purposes. In the following section I provide a critical overview of the shifts in policy approach to the medium of instruction since independence. For the sake of consistency, I will refer to the indigenous vernaculars as local languages.

\section{Medium-of-instruction policy 2000-2008}

In the aftermath of the 1999 emergency, education planning focused on the challenges of changing from an Indonesian curriculum to one that was considered more appropriate for the independent nation. These challenges involved not only changing curriculum content but also the medium of instruction. Despite rhetorical statements claiming that it was a key goal to reintroduce 
both Portuguese and Tetum as languages of instruction (MECYS, ${ }^{5}$ Education and Training 10; Education Policy 20-24), policy directives consistently privileged Portuguese and were indecisive about the place and value of Tetum in the curriculum. These directives veered between insisting that teachers teach exclusively in Portuguese and more permissive but contradictory guidelines on teachers' use of Tetum.

In the transitional period to formal independence in 2002, medium-ofinstruction policy focused on the rapid reintroduction of Portuguese. Indonesian was to be phased out of the curriculum by 2009 and Portuguese was designated as the sole language of instruction. This curriculum model also delivered Portuguese as a subject for 4 hours a week. Medium-of-instruction policy for 2004-2008 continued to focus on hastening the reintroduction of Portuguese but now allotted time for the teaching of Tetum as a subject in the early years. Commencing from September 2005, the curriculum balance shifted from 5 hours a week of Tetum and 3 hours of Portuguese as subjects in Grades 1 and 2 to 6 hours a week of Portuguese and 2 hours a week of Tetum by Grade 6 (MECYS, Education Policy 17). The Ministry of Education (MOE) issued the following orientations to teachers regarding the use of Tetum in the classroom:

Overall, since Tetum is at a preliminary stage of development, the implementation of Portuguese will have precedence, and Tetum may be used as a pedagogic aide in the teaching of disciplines related to the environment, social sciences, history and geography. (MECYS, Education Policy 11)

This telling statement clearly illustrates the low esteem in which Tetum was held as a language of instruction, deemed only worthy of use as an adjunct to Portuguese. The MOE curriculum framework document described the objective for the teaching of languages as "the development of two languages at the same time in a process of mutual enrichment" (MECYS, Education Policy 9) and went on to state that early literacy would be taught in Tetum. However, although policy statements accorded Tetum the status of a language of literacy and recognised that it should be formally taught, as the extract above shows, it was relegated to use only in certain subject areas (Quinn 256). The focus 
on reintroducing Portuguese also included compulsory language training for teachers in Portuguese and the development of bilingual Portuguese/Tetum teaching materials. In view of overall low rates of parental literacy in the coofficial languages, these goals were unlikely to support the concomitant goals of developing parent-teacher associations and reinforcing the role of parents and of communities in school life (MECYS, Education Policy 20-24).

The widespread violence and political crisis of 2006-2007, ${ }^{6}$ the 2007 elections, and a subsequent change of government meant that all policy plans were stalled. Recognising the urgent need to build national consensus, the new constitutional government allocated greater funding to the education sector in conjunction with a mandate for educational reform. In April 2008, the incoming Ministry issued new guidelines that allowed the use of both Portuguese and Tetum as languages of instruction. In terms of the allocation of curriculum time, these guidelines stipulated that teachers' language use should shift from roughly 70\% Tetum and 30\% Portuguese in Grade 1 to 100 percent Portuguese by the end of Grade 3. From Grade 4, Portuguese was designated the language of instruction and the only written language, while Tetum was to be used for oral instruction only (MOE, Helping Children Learn 10). This model clearly privileged Portuguese and did little to provide clarity for teachers. By this stage, policy seemed to be stuck in an ideological impasse. In addition, various forms of learning assessment showed repeatedly that East Timorese schoolchildren's literacy and numeracy were well below par; for example, in 2009 an Early Grade Reading Assessment conducted in 40 primary schools found that not only were children performing at half the expected rate for effective reading (60 words a minute) but their reading comprehension was far below international standards for their age (World Bank 3).

\section{Recent EFA initiatives}

The policy impasse was finally broken by a series of Government initiatives to provide free primary and secondary education for all. These reforms have introduced a new more humanistic and localised discourse into development planning by acknowledging the need to improve educational quality in order to promote social inclusion. In 2008 an important piece of legislation was passed 
which reformed the structure of the education system. The Basic Education Act guarantees all citizens access to nine years' compulsory, free basic education (MOE, Education System). The new system also prioritises the expansion and enhancement of pre-school provision. Educational reform and the new emphasis on social inclusion have prompted a reappraisal of language in education.

The Basic Education Act marks a significant change in perspective on the languages of instruction. Whereas in previous documents Portuguese took priority and Tetum held the status of an auxiliary language, Article 8 establishes that the teaching languages of the East Timorese education system are Tetum and Portuguese. In June 2011, the Council of Ministers also approved plans for the teaching of both languages as subjects in the curriculum. According to the approved timetable model, the teaching of Tetum as a subject takes priority between years 1 and 3 (3-4 periods a week) while the teaching of Portuguese takes up more curriculum time (5 periods a week) in years 7 through 9. English, as the designated first foreign language, may be introduced in years 5, 6 or 7 according to the capacity of the school (RCDEB 20-21).

The Timor-Leste Strategic Development Plan is a package of social policies that include educational development planning for 2011-2030. Two statements in this plan have such important implications for language in education that they are quoted here in full. The first declares:

To improve access to education, and build a solid foundation for future literacy and numeracy in both Portuguese and Tetum, local languages will be employed as languages of teaching and learning in the first years of basic education, providing a smooth transition to the acquisition of Timor-Leste's official languages, in accordance with the recommendations of the mother tongue-based multilingual education policy for Timor-Leste. (TLSDP 16)

The second statement acknowledges that children who do not speak the official language(s) at home can be disadvantaged by their use in schools, declaring:

Given the diversity of national and local languages in Timor-Leste, the National Education Commission has initiated studies on mother tongue- 
based multilingual education for Timor-Leste. These studies aim to ensure that children are not disadvantaged and that all have equal access to an education, providing a smooth initial transition to the acquisition of TimorLeste's official languages. (TLSDP 25)

These statements mark a turning point in perceptions of the use of local languages in education. Both statements refer to the mother tongue-based multilingual education (MTB-MLE) policy initiative. In what follows I present an explanation of the principles of MTB-MLE followed by a summary and discussion of the policy recommendations for Timor-Leste.

Mother tongues and mother tongue-based multilingual education (MTB-MLE)

The term mother tongue (lian inan in Tetum, lingua materna in Portuguese) is widely used to describe the language(s) an individual speaks in the home and/or community. The term is problematic because many multilinguals may consider several languages to be their mother tongues, particularly in the linguistically diverse countries of the South (Benson, "How Multilingual" 324). The United Nations defines a mother tongue or first language (L1) as the language one has (a) learned first; (b) identifies with or is identified by others; (c) knows best; and (d) uses most (Skutnabb-Kangas; UNESCO, Education in a Multilingual World 15). A useful definition of L1 for educational purposes is that it is a language one speaks and understands competently enough to learn academic content at the appropriate age level (Kosonen and Young 12). This definition allows for the fact that although children may use one language at home, they may also speak another community language well enough to understand it at school.

In principle, MTB-MLE programs enable learners to begin their education in the language they know best. Learners are gradually introduced to additional (official) languages and learning to communicate in these languages. The most effective programs develop both multilingualism and multiliteracy by building on L1 oral and literate competence, while teaching additional language(s) (Benson, "How Multilingual" 329). These programs are known as strong or additive 
MTB-MLE programs. In strong MTB-MLE programs, learners use their L1 for early learning and literacy development. Teachers help develop their academic vocabulary in the additional school language(s) so they can understand and talk about more abstract concepts (Thomas and Collier). As learners gain competence in the additional language(s), teachers begin using them for teaching curriculum content. ${ }^{7}$ In this approach, learners are better able to achieve grade-level subject competence because teachers use their L1, along with the additional school language(s), to help them understand academic concepts.

Increasing evidence from countries of the global South shows that MTBMLE programs improve educational participation and outcomes. ${ }^{8}$ The strongest forms of MTB-MLE show the best results. Strong MTB-MLE programs maintain L1s throughout the primary years. For instance, studies in Ethiopia and the Philippines provide longitudinal evidence that maintaining L1s in the curriculum for as long as possible improves literacy and numeracy outcomes. ${ }^{9}$ In the new MTBMLE guidelines Timor-Leste can boast some of the most ambitious proposals in Southeast Asia to date to guide education policy development.

\section{The MTB-MLE policy recommendations for Timor-Leste}

In 2009 the MOE requested the National Education Commission (NEC), the Ministry's key advisory body, to develop a policy on language use in schools taking into account international best practice in multilingual settings. In early 2010, the Ministry mandated the NEC to form a language-in-education working group to prepare language policy guidelines and planning strategies with a focus on pre-primary education and compulsory basic education. In consultation with international specialists, this working group produced the MTBMLE policy for Timor-Leste.

The MTB-MLE policy recommends using first languages (L1s) for initial instruction with the gradual introduction of Tetum and Portuguese and the later addition of Indonesian and English while maintaining the L1s in the system for as long as possible. Mother tongues are defined as the home languages of learners or L1s, even where there are two or more home languages because the teaching focus is on the language the learner knows best (NEC, National Policy 9). This could also include a language spoken widely in the local community. 
Tetum is considered the L2 for most children, although it is acknowledged that Tetum should be regarded as L1 for teaching purposes in some communities; Portuguese is regarded as L3, English as L4 and Indonesian as L5. English and Indonesian are not prioritised until the third cycle of basic education, where it is recommended that English is introduced as a compulsory subject in Grade 7. Recognising Indonesian as an important regional language, the guidelines keep Indonesian in the system rather than phasing it out, as earlier policy stipulated; instead they recommend the introduction of Indonesian as an elective subject in the first year of secondary education (i.e. Grade 10).

The major departure from previous policy lies in the provisions for use of the national languages. The MTB-MLE policy recommends that L1s be used as languages of instruction from pre-primary school until the end of Grade 3. Tetum should be used orally by teachers from pre-primary to Grade 1, then used as an instructional language with L1 and taught as a subject from Grades 2 and 3 onwards. Portuguese should be used orally from Grades 1 through 3, then both taught as a subject and used as an instructional language from Grade 4 alongside Tetum (and L1 if possible). Portuguese and Tetum should be the instructional languages in secondary education (NEC, National Policy 18-19).

In early 2012 the first MTB-MLE pilot project commenced in twelve pre-primary and primary schools in the districts of Oecusse, Manatuto and Lautem, districts where people communicate primarily in their local languages. Following the MTB-MLE policy recommendations, teaching assistants who speak the local languages have been employed to support teachers and several community-based Councils for the Promotion of Mother Tongue have been formed to help teachers develop orthographies for use in reading and teaching materials. Children's performance in the pilot schools (known as demonstration schools) will be tracked and compared with student performance in mainstream schools. Feedback will be sought from the local communities on the demonstration schools (NEC, Implementation Plan 12). Medium to long-term goals include integrating MTB-MLE into teacher training programs, producing MTB-MLE training and curriculum materials in Tetum and Portuguese and revising the basic education curriculum in alignment with MTB-MLE principles (NEC, Implementation Plan 4-5). Long-term goals include expanding 
MTB-MLE and developing teacher training and materials in as many local languages as possible (NEC, Implementation Plan 5).

\section{Concerns about MTB-MLE}

It is often the case in countries with colonial histories that former colonial languages continue to be privileged over indigenous languages in formal schooling, a policy often justified by the supposed neutrality and international reach of these languages (Harbert et al. 12). Moreover, these dominant languages are invariably regarded as the only legitimate languages to be used in education because indigenous varieties are regarded as unsuitable, irrelevant or intellectually, socially and linguistically inferior. Concerns expressed about MTB-MLE in Timor-Leste tend to reflect this widely held but erroneous belief.

One concern is that MTB-MLE undermines the learning of the official languages. This perception often leads people to think that the earlier official languages are introduced into the curriculum, the better. However, there is no sound educational evidence that starting early leads to better learning of additional languages. On the contrary, evidence shows that children whose mother tongues are well developed are able to transfer these skills to additional languages. Research studies show that children taught in the languages they know best also develop numeracy skills better than those who are not (UNESCO, Mother Tongue Matters).

Another concern is that MTB-MLE creates social division and threatens national unity. However, successful MTB-MLE programs can help promote social inclusion and national integration through their recognition of diverse ethnolinguistic identities. ${ }^{10}$ Literate and numerate citizens are better equipped to participate in the public life and the political affairs of their country. Moreover, a literate population has better access to information about health, nutrition and wellbeing. ${ }^{11}$ Strong multilingualism and literacy can help break the cycle of underachievement and low education levels, offering a way out of poverty and a pathway towards active citizenship.

Multilingual education for all?

The MTB-MLE policy proposals provide a structured approach to the teaching and use of languages in education that can invigorate policy and support 
both learners and teachers. If the proposals are given the opportunity to be effectively implemented and extended, the policy has the potential to improve learning and strengthen engagement in schooling. By recognising children's right to learn in the language of their home or learning community, teachers can promote social inclusion, instil pride in their pupils' ethnolinguistic identities and build a strong sense of national identity, one which valorises the languages and cultures of all citizens. ${ }^{12}$ The MTB-MLE policy recommendations for Timor-Leste offer the best guarantee that schools will produce literate citizens and competent speakers of the co-official languages (NEC, National Policy and Implementation Plan; Taylor-Leech, "Timor-Leste").

Language policies can work to promote or undermine cultural diversity and social inclusion. Brenzinger (37) highlights this point when he writes that exclusion from access to education and wellbeing constitutes a form of poverty. Indeed, as Batibo (29) also points out, it is usually the speakers of less privileged languages that become the most socially marginalised and economically disadvantaged in society. Policymakers should therefore take on board the critical role that linguistic exclusion plays in denying access to the educational resources which can help combat poverty. Moreover, it is vital for policymakers to appreciate that it is not only former colonial languages that can threaten diversity. The privileging of one local indigenous language over others can also have devastating effects on minority languages. Experience in Africa shows how policies that elevate indigenous lingua francae to take on new roles in high status domains like education, administration, the judicial system and parliamentary affairs, bring these languages more political, social and economic prestige (Batibo 30). This process encourages people to shift to the use of these lingua francae from indigenous minority languages, a process that eventually results in a reduction of linguistic diversity. Loss of diversity leads to the weakening and eventual loss of local, indigenous knowledge, culture and traditions. Although estimates from various sources vary considerably, it is generally agreed that oral (as opposed to literate) competence in Tetum-Praça has spread extensively since the 1980s. While for the present, most East Timorese hold strong attachment to their local languages, continued language shift to Tetum over the coming generations can be predicted. It follows therefore that 
language-in-education policies should treat linguistic diversity as a resource and a development asset rather than a problem or liability (Batibo 29) if the continued vitality of the local languages is to be ensured.

It would be foolhardy to claim that MTB-MLE is problem-free or that it can provide an overnight solution to all the human development challenges facing Timor-Leste. There are doubts, misunderstandings and controversies, albeit mostly of an ideological nature, surrounding multilingual education. But there is also substantial and convincing evidence, coming from postcolonial countries in particular, that it provides the best means of achieving universal education and literacy. For EFA and the achievement of the MDGs to become a reality, it is essential to reach out to people in their own languages. The success of the demonstration schools will be vital in gaining public confidence and convincing the Government that investment in MTB-MLE is worthwhile. Experience shows that effective MTB-MLE not only enhances the learning of official languages but also helps increase enrolment and retention, improve educational achievement and involve local communities in the life of the school. If the MTB-MLE policy guidelines are promulgated by the government, Timor-Leste could become a shining example for others to follow in showing the steps that can be taken to protect linguistic diversity and achieve multilingual education for all.

\section{Notes}

1 UNESCO indices show that net primary enrolment is lower than all other countries in the region; e.g. Brunei Darussalam and Malaysia, 97\%; Indonesia, 98\%; Philippines, 92\%; Cambodia, 89\%; and Laos, 82\% (Mother Tongue Matters).

2 For example, see: Benson, "The Importance of Mother Tongue-based Schooling for Educational Quality" and Girls, Educational Equity and Mother Tongue; Chimbutane; Hunt; Ouane.

3 For example, see: Ball; Cummins, Language, Power and Pedagogy, and Negotiating Identities; UNESCO, The Use of Vernacular Languages in Education; World Declaration on Education for All; Advocacy Kit for Promoting Multilingual Education; and Mother Tongue Matters.

4 For detailed overviews of the language situation, see also Hajek; Hull; Taylor-Leech, "The Language Situation" and "Timor-Leste: Sustaining and Maintaining the National Languages in Education;" Thomaz.

5 At that time the Ministry of Education was known as the Ministry of Education, Culture, Youth and Sport.

6 For details, see: Anderson; Kingsbury; Muggah. 
7 See UNESCO, Advocacy Kit for Promoting Multilingual Education: Including the Excluded and Promoting Literacy in Multilingual Settings.

8 For example, see: Bolivia (Hornberger and Swineheart; López), China (Geary and Pan), Guinea-Bissau, Cambodia, Ethiopia, and Mozambique (Benson, "How Multilingual African Contexts are Pushing Educational Research and Practice in New Directions"), Papua New Guinea (Easton; Pickford), Philippines (Dekker and Young; Malone; Young, "First Language First" and "First Language"), Vietnam, Cambodia, Thailand, and Philippines (Kosonen and Young; Middleborg; Thomas).

9 See: Alidou, et al.; Heugh; Heugh, et al.; Nolasco; Walter and Dekker.

10 For example, see: Ouane; Skutnabb-Kangas and Heugh.

11 For an excellent overview of ways in which MTB-MLE can empower communities and give them the tools to achieve the Millennium Development Goals, see SIL International.

12 For example, see: Ball; Skutnabb-Kangas.

\section{Works cited}

Alidou, Hassana, Aliou Boly, Brigit Brock-Utne, Yaya Satina Diallo, Kathleen Heugh and H. Ekkehard Wolff. Optimizing Learning and Education in Africa: The Language Factor. A Stock-taking Research on Mother Tongue and Bilingual Education in Sub-Saharan Africa. Association for the Development of Education in Africa (ADEA), Paris, 2006. Web. 3 May 2011.

Anderson, Timothy. “Timor-Leste: The Second Intervention.” Journal of Australian Political Economy 58 (2006): 62-93. Print.

Ball, Jessica. Enhancing Learning of Children from Diverse Language Backgrounds: Mother Tongue-based Bilingual or Multilingual education in the Early Years. UNESCO, Paris, 2010. Web. 19 November 2012.

Batibo, Herman. "Poverty as a Crucial Factor in Language Maintenance and Language Death: Case Studies from Africa." Language and Poverty. Ed. Wayne Harbert with the help of Sally McConnell-Ginet, Amanda Miller and John Whitman. Bristol, Buffalo, Toronto: Multilingual Matters, 2009. 23-36. Print.

Benson, Carol. "The Importance of Mother Tongue-based Schooling for Educational Quality." Paper commissioned for the EFA Global Monitoring Report, The Quality Imperative. UNESCO, Paris, 2005. Web. 19 November 2012.

—. Girls, Educational Equity and Mother Tongue. UNESCO, Bangkok, 2005. Web. 19 November 2012.

"How Multilingual African Contexts are Pushing Educational Research and Practice in New Directions." Language and Education 24.4 (2010): 323-336. Print.

Bowden, John and John Hajek. "Not just Tetum: Language Development and the Case of Waima'a." East Timor: Beyond Independence. Eds. Michael Leach and Damian Kingsbury. Clayton, Vic: Monash Asia Press, 2007. 263-274. Print.

Brenzinger, Matthias. "Language Diversity and Poverty in Africa." Language and Poverty. Ed. Wayne Harbert with the help of Sally McConnell-Ginet, Amanda Miller and John 
Whitman. Bristol, Buffalo, Toronto: Multilingual Matters, 2009. 37-49. Print.

Chimbutane, Feliciano. Rethinking bilingual education in postcolonial contexts. Clevedon, UK: Multilingual Matters, 2011. Print.

Cummins, Jim. Language, Power and Pedagogy: Bilingual Children in the Crossfire. Clevedon, UK: Multilingual Matters, 2000. Print.

- Negotiating Identities: Education for Empowerment in a Diverse Society. Ontario, CA: Association for Bilingual Education, 2001. Print.

Dekker, Diane and Catherine Young. "Bridging the Gap: The Development of Appropriate Educational Strategies for Minority Language Communities in the Philippines." Current Issues in Language Planning 6.2 (2005):182-199. Print.

Easton, Catherine. "Alphabet Design Workshops in Papua New Guinea: A Community-based Approach to Orthography Development." International Conference on Language Development, Language Revitalization and Multilingual Education. Bangkok, Thailand. 7-9 November 2003. Web. 3 May 2011.

Geary, D. Norman and Yongrong Pan. "Eight Hundred Stories for Dong Development: A Bilingual Education Pilot Project in Guizhou Province, China." 6th Oxford International Conference on Education and Development. Oxford, UK. 19-21 September 2001. Conference Presentation.

Hajek, John. "Language Planning and the Sociolinguistic Environment in East Timor: Colonial Practice and Changing Language Ecologies." Current Issues in Language Planning 1 (2000): 400-413. Print.

Harbert, Wayne, Sally McConnell-Ginet, Amanda Miller and John Whitman. "Introduction." Language and Poverty. Ed. Wayne Harbert, Sally McConnell-Ginet, Amanda Miller and John Whitman. Bristol, Buffalo, Toronto: Multilingual Matters, 2009. 1-19. Print.

Heugh, Kathleen. "Productive Engagement with Linguistic Diversity in Tension with Globalised Discourses in Ethiopia." Current Issues in Language Planning 11.4 (2010): 378-396. Print.

Heugh, Kathleen, Carol Benson, Berhanu Bogale and Mekonnen Alemu GebreYohannes. Final Report: Study on Medium of Instruction in Primary Schools in Ethiopia. SeptemberDecember 2006. Ethiopia, Ministry of Education, Addis Ababa, January 22, 2007. Web. 19 November 2012.

Hull, Geoffrey. “The Languages of Timor 1772-1997. A Literature Review." Studies in Languages and Cultures of East Timor 1 (1998): 1-38. Print.

Hunt, Frances. Dropping out from School: A Cross-country Review of Literature. CREATE Pathways to Access No 16. Consortium for Research on Educational Access, Transitions and Equity. University of Sussex, 2008. Web. 30 November 2012.

Hornberger, Nancy \& Karl Swinehart. "Not Just Situaciones de la Vida: Professionalization and Indigenous Language Revitalization in the Andes." International Multilingual Research Journal 6.1 (2012): 35-49. Print.

Kingsbury, Damien. “East Timor's Political Crisis: Origins and Resolution.” Ed. David Mearns. Democratic Governance in Timor-Leste: Reconciling the Local and the National. Darwin, NT: Charles Darwin UP, 2008. 33-35. Print.

Kosonen, Kimmo and Catherine Young. Mother Tongue as a Bridge Language of Instruction: Policies and Experiences in Southeast Asia. SEAMEO, Bangkok, 2009. Web. 19 November 2012. 
Lewis, M. Paul. Ethnologue: Languages of the World. Dallas, Tex.: SIL International. Sixteenth edition. 2009. Web. 19 Nov 2012.

López, Luis, E. "Literacy and Intercultural Bilingual Education in the Andes." Eds. David R. Olson \& Nancy Torrance. Literacy and Social Development: The Making of Literate Societies. Malden, MA: Blackwell, 2001. 201-224. Print.

Malone, Susan. "First Language First: Community-based Literacy Programmes for Minority Language Contexts." Education for Multilingualism and Multi-literacy in Ethnic Minority Communities: The Situation in Asia. Bangkok: UNESCO, 2005. 71 - 86. Print.

MECYS [Ministry of Education, Culture, Youth and Sports]. Education and Training: Priorities and Proposed Sector Investment Program. Dili: RDTL, 2004. Print.

—. Education Policy 2004 - 2009. Dili: RDTL, 2004. Print.

Middleborg, Jorn. Highland Children's Education Project: Good Lessons Learned in Basic Education. UNESCO, Bangkok, 2005. Print.

“The Millenium Development Goals. Eight Goals for 2015.” United Nations Development Programme. United Nations Development Programme, n.d.Web. 15 February 2013.

MOE [Ministry of Education], Government of Timor-Leste. Education System Framework Law 14/2008. Dili, RDTL, 2008. Web. 20 April, 2012.

- Helping Children Learn: An International Conference on Bilingual Education in TimorLeste. Dili, RDTL, 2008. Print.

—. National Education Strategic Plan [NESP] 2010-2015. Dili: RDTL, 2009. Print.

Muggah, Robert. Ed. Urban Violence in an Urban Village. A Case Study of Dili, Timor-Leste. Geneva, Switzerland: Geneva Declaration Secretariat, 2010. Print.

National Bureau of Statistics [Direção Nacional de Estatística] and United Nations Population Fund [UNFPA]. National Priority Tables: Census of Population and Housing 2004. Dili, RDTL, 2006. Print.

NEC [National Education Commission], Ministry of Education. Mother Tongue-based Multilingual Education for Timor-Leste: National Policy. Dili, RDTL 2010. Print.

—. Mother Tongue-based Multilingual Education for Timor-Leste: Implementation Plan. Dili, RDTL, 2010. Print.

Nolasco, Ricardo. Twenty-one Reasons Why Filipino Children Learn Better While Using their Mother Tongue. A Primer on Mother Tongue-based Multilingual Education (MLE) and Other Issues on Language and Learning in the Philippines. Guro Formation Forum, University of the Philippines, Quezon City, 2009. Web. 30 November, 2012.

Ouane, Adama. Towards a Multilingual Culture of Education. Hamburg: UNESCO Institute for Education, 2003. Print.

Pickford, Steve. "Emerging Pedagogies of Linguistic and Cultural Continuity in Papua New Guinea." Language, Culture and Curriculum 18.2 (2005): 139-153. Print.

Pinnock, Helen, Pamela Mackenzie, Elizabeth Pearce and Catherine Young. Closer to Home: How to Help Schools in Low - and Middle-income Countries Respond to Children's Language Needs. CFBT Education Trust and Save the Children International, 2011. Web. 19 November 2012.

Quinn, Marie. "The Challenge of Realising Language and Literacy Goals in East Timorese Classrooms." East Timor: Beyond Independence. Eds. Damien Kingsbury and Michael Leach. Melbourne: Monash UP, 2007. 251 - 262. Print. 
RCDEB [Reforma Curricular de Ensino Básico: Princípios Orientadores e Plano de Desenvolvimento]. Braga and Porto: Instituto de Educação, Universidade do Minho, Portugal and Escola de Educação, Insituto Politécnico do Porto, 2010. Print.

Sabates, Ricardo, Kwame Akyeampong, Jo Westbrook and Frances Hunt. "School Dropout: Patterns, Causes, Changes and Policies." Background paper prepared for the EFA Global Monitoring Report 2011: The hidden crisis: Armed conflict and education. Paris: UNESCO Publishing, 2010. Web. 30 November 2012.

SIL International. Why Languages Matter: Meeting Millennium Development Goals through Local Languages. SIL International, n.d. Web. 30 November 2012.

Skutnabb-Kangas, Tove. Linguistic Genocide in Education - or Worldwide Diversity and Human Rights? Mahwah, NJ: Lawrence Erlbaum Associates. 2000. Print.

Skutnabb-Kangas, Tove and Kathleen Heugh, eds. Multilingual Education and Sustainable Diversity Work: From Periphery to Center. New York and London: Routledge, 2011. Print.

Smits, Jeroen, Janine Huisman and Karine Kruijff. "Home Language and Education in the Developing World." 2008. Commissioned Study for the EFA Global Monitoring Report. Overcoming Inequality: Why Governance Matters. UNESCO, 2009. Web. 19 November 2012.

Taylor-Leech, Kerry. "The Language Situation in Timor-Leste." Current Issues in Language Planning 10.1 (2009): 1-68. Print.

_. "Timor-Leste: Sustaining and Maintaining the National Languages in Education." Current Issues in Language Planning 12.2 (2011): 289-308. Print.

Thomas, Anne. "Bilingual Community-based Education in the Cambodian Highlands. A Successful Approach for Enabling Access to Education by Indigenous Peoples." Journal of Southeast Asian Education 3.1 (2002): 26-58. Print.

Thomas, Wayne and Virginia Collier. A National Study of School Effectiveness for Language Minority Students' Long-term Educational Achievement. Center for Research on Education, Diversity and Excellence. 2002. Web. 19 November 2012.

Thomaz, Luís. "The Formation of Tetum-Praça, Vehicular Language of East Timor." Papers on Indonesian Languages and Literatures. Eds. Nigel Phillips and Khaidir Anwar. London: School of Oriental and African Studies, 1981. 54-83. Print.

TLSDP [Timor-Leste Strategic Development Plan 2011-2030]. Dili, RDTL, 2011. Print.

Trudell, Barbara. "When 'Prof' Speaks, Who Listens? The African Elite and the Use of African Languages for Education and Development in African Communities." Language and Education 24.4 (2010): 337-352. Print.

UNESCO. Advocacy Kit for Promoting Multilingual Education: Including the Excluded. UNESCO, Bangkok, 2007. Web. 19 November 2012.

—. Education. UNESCO, n.d. Web. 15 February 2013.

- Education in a Multilingual World. UNESCO, Paris, 2003. Web. 19 November 2012.

Mother Tongue Matters: Local Language as a Key to Effective Learning. UNESCO, Paris, 2008. Web. 26 November 2012.

—. Promoting Literacy in Multilingual Settings. UNESCO, Paris, 2007. Web 19 November 2012.

—. The Use of Vernacular Languages in Education. UNESCO, Paris, 1953. Web. 19 November 2012. 
-World Declaration on Education for All and Framework for Action to Meet Basic Learning Needs. UNESCO, Paris, 1990. Web. 19 November 2012.

Walter, Stephen and Diane Dekker. The Lubuagan Mother Tongue Education Experiment (FLC). A Report of Comparative Test Results. Committee on Basic Education and Culture; Committee on Higher and Technical Education, House of Representatives, Republic of the Philippines, Quezon City, 2008. Web. 19 November 2012.

World Bank. Timor-Leste: An Analysis of Early Grade Reading Acquisition. Washington: Human Development Sector Unit East Asia and Pacific Region. Working paper 56909-WPO. 2009. Web. 19 November 2012.

Young, Catherine. "First Language First: Literacy Education for the Future in a Multilingual Philippine Society." International Journal of Bilingual Education and Bilingualism 5.4 (2002): 221-232. Print.

"First Language. A Foundation for Effective Basic Education." Philippine Journal of Linguistics 34. 1 (2003): 123-131. Print.

Kerry Taylor-Leech is a lecturer and researcher in Applied Linguistics in the School of Education and Professional Studies at Griffith University, Queensland, Australia. Her research focuses on multilingualism, in particular the intersections between language policy, development, identity, education and literacy. Her research connections with Timor-Leste date from 2001. 